Utah State University

DigitalCommons@USU

1990

\title{
Pine Hollow exclosures: effect of browsing on an aspen community sprayed with 2,4-D
}

\author{
D.L. Bartos
}

R.O. Harniss

Follow this and additional works at: https://digitalcommons.usu.edu/aspen_bib

Part of the Forest Sciences Commons

\section{Recommended Citation}

Bartos, D.L. and Harniss, R.O., "Pine Hollow exclosures: effect of browsing on an aspen community sprayed with 2,4-D" (1990). Aspen Bibliography. Paper 3008.

https://digitalcommons.usu.edu/aspen_bib/3008

This Report is brought to you for free and open access by the Aspen Research at DigitalCommons@USU. It has been accepted for inclusion in Aspen Bibliography by an authorized administrator of DigitalCommons@USU. For more information, please contact

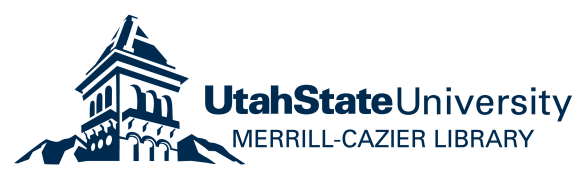


United States

Department

of Agriculture

Forest Service

Intormountain

Research Station

Research Note

INT-393

November 1990

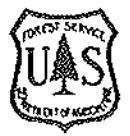

Pine Hollow Exclosures: Effect of Browsing on an Aspen Community Sprayed Dale L. Bartos
Roy O. Harniss'

\section{ABSTRACT}

The Pine Hollow aspen (Populus tremuloides) exclosures on the Ashley National Forest in eastern Utah were sampled in 1984, 19 years after they were established. The effects of 2,4-D, wildlife, and cattle on plant succession were evaluated. Two exclosures were used to protect the sprayed area from (1) all animal use and (2) only livestock use. A third sprayed area was left open for use by all animals. The aspen overstory was killed as a result of spray. ing, with sufficient reproduction occurring to restock the stand. However, animal use drastically altered the aspen reproduction, as well as the understory production. Total protection favored desirable understory species while the open area had fewer desirable species.

KEYWORDS: Populus tremuloides, wildlife, livestock, understory, production

Old Forest Service administrative studies help us gain insight into current management problems.

The Pine Hollow wildlife and cattle exclosures are an example. Old files and the collection of new data have enabled us to follow the effects of 2,4-D and of wildlife and cattle on plant succession in aspen over a 19-year period. A similar approach proved beneficial in interpreting vegetation changes associated with clearcut aspen on the Fishlake National Forest in southern Utah (Mueggler and Bartos 1977).

\section{SETITING}

The Pine Hollow exclosures are on the eastern edge of the Taylor Mountain Plateau on the Ashley

\footnotetext{
${ }^{2}$ Authors are operations research analyst and range scientist (retired), Intermountain Research Station, Logan, Urt.
}

National Forest in eastern Utah. Aspen (Populus tremuloides Michx.) in this area occupies relatively arid marginal sites that grade into sagebrush steppe. As a consequence, aspen is generally low in stature and scrubby in form (fig. 1). Similar scrub aspen occurs on vast areas between 2,286 and $2,743 \mathrm{~m}$ elevation across the southern slopes of the Uinta Mountains. This vegetation type borders lodgepole pine (Pinus contorta Dougl.) at the upper limits and sagebrush-grass at the lower elevations. The landscape of the aspen scrub type consists of large expanses of aspen interspersed with shrubdominated openings. The understory vegetation consists primarily of grass and sedges with an abun dance of big sagebrush (Artemisia tridentata Nutt. vaseyana [Rydb.] Beetle). Big sagebrush also dominates the interspaces. Some areas support an abundance of dwarf juniper (Juniperus communis L. var. saxatilis Pall.). Broadleaf forbs such as geranium (Geranium viscosissimum F.\& M.), lupine (Lupinus spp.), and aster (Aster spp.) are present but not abundant. The area would be classified as a Populus tremuloides / Artemisia tridenta, Populus tremuloides/Juniperus communis, or Populus tremuloides/Juniperus communis/Lupinus argenteus community type (Mueggler 1988).

Historically this area has been important summer range for livestock and is used extensively by wild. ungulates. The exclosures were established within an area considered important mule deer (Odocoileus hemionus) and elk (Cervus elaphus) range. Elk use the area on a yearly basis while deer use it mainly during the spring and fall with periodic use occurring during "open" winters. From 1966 through 1971 , deer made considerably more use of the site than elk during the summer (Davis 1989).

By the mid-1900's, overuse of forage on this range became obvious. This abuse was attributed in large part to livestock, in particular sheep. Intensive rest-rotation grazing practices were implemented 


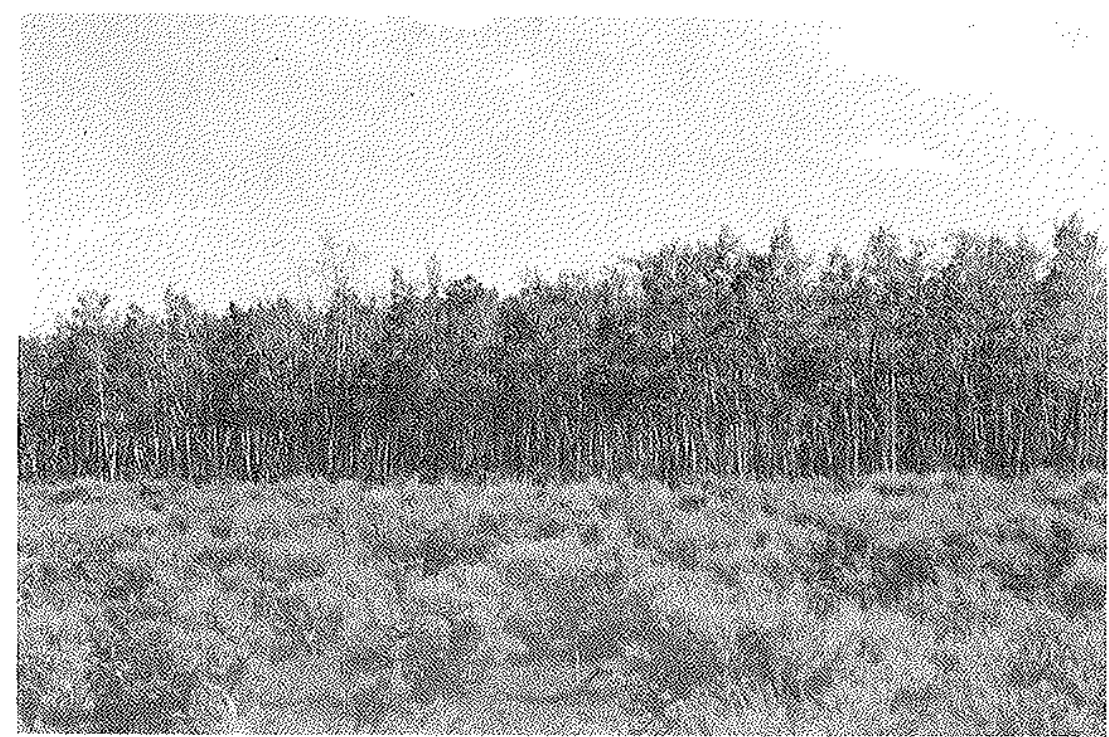

Figure 1-General view of Pine Hollow in 1965 prior to treatment by herbicide. Note the highlining of the aspen. on the grazing allotment, which appears to have reduced the overuse problem. Wildlife appeared not to have contributed significantly to the overuse problem because of low densities distributed across large areas.

Prior to the treatment, land managers believed that these scrub aspen sites were producing less than their potential in resource products. These managers anticipated that removing the existing aspen overstory by a herbicide treatment would temporarily reduce the competitive effects of both aspen and sagebrush. This would then permit an increase in the vigor and production of grass and grasslike species and a profusion of aspen suckers. No negative effects on ground cover or watershed values were expected. Apparently the deleterious effects of the herbicide on the broadleaf vegetation were not emphasized because of the lack of desirable forbs on the site prior to treatment.

\section{APPROACH}

On June 23,1965 , about 40 ha of scrub aspen were sprayed by helicopter with low-volatile $2,4-\mathrm{D}$ ester at a rate of $2.2 \mathrm{~kg}$ acid equivalent per hectare using a diesel-oil carrier. The treated site is on the Vernal District of the Ashley National Forest approximately $28 \mathrm{~km}$ north of Vernal, UT. The Pine Hollow administrative study (Laycock 1969) is a part of the Brush Creek Grazing Allotment at the lower edge of the aspen zone at about $2,530 \mathrm{~m}$ elevation in Sec. 3, T2S., R21E., Uintah County. Four 0.8-ha macroplots were established in the area; three were sprayed and the fourth served as a control. One sprayed macroplot consisted of a game exclosure where the vegetation was protected from use by all large ungulates. An adjacent sprayed macroplot was an exclosure that excluded livestock but was open to wildlife use. The third sprayed macroplot was an adjacent area open to use by both wildlife and livestock. The control area was some distance removed and was open to use by both wild. life and livestock. The two exclosures were constructed of woven wire ( $2.4 \mathrm{~m}$ high for the game exclosure and $1.2 \mathrm{~m}$ for the livestock exclosure) immediately after the site was treated.

Aspen reproduction, other vegetation, and animal use were sampled in 1965,2 weeks prior to treat. ment to determine pretreatment conditions. Within each of the four areas, 30 plots were systematically laid out. Alternate plots were permanently marked with steel angle iron. All plots were evenly placed in three transects with 10 plots ( $9 \mathrm{~m}$ apart) per transect. The early data collectors used a $0.09-\mathrm{m}^{2}$ circular quadrat at each plot location to determine species composition, production ( $\mathrm{kg} / \mathrm{ha}$ ), and ground cover using the "hoop-weight estimate method" (U.S. Department of Agriculture 1983). Production was expressed on a dry weight basis. In addition, individual stems of aspen trees and percentage of cover of trees and shrubs were determined on the 15 even-numbered plots using a $9.3-\mathrm{m}^{2}$ circular quadrat $\left(18.6-\mathrm{m}^{2}\right.$ circular quadrats were used in $1966,1967,1968$, and 1969). Animal use was monitored on the three areas that animals had access to. Fecal counts were made on $18.6-\mathrm{m}^{2}$ circular quadrats at each plot center to determine relative use by deer, elk, and cattle. Quadrats were swept to determine animal use. Vegetation and animal use measurements on these quadrats were repeated in 1966, $1967,1968,1969$, and 1984 . The control area was not sampled in 1966 or 1968 . Such measurements enable tracing the sequence of successional change 
after herbicide treatment and of change attributable to protection from grazing.

Our objective in 1984 was to duplicate the earlier sampling as closely as possible. All the initial measurements were repeated except for production and cover of understory vegetation, which we modified. We used the $0.09-\mathrm{m}^{2}$ circular quadrat at each plot location to estimate cover, and then each quadrat was clipped to determine production and species composition. The quadrats were clipped by species to ground level, dried, and weighed. Production was expressed as an average of 30 quadrats converted to kilograms dry weight per hectare. Aspen trees and suckers were counted by size classes on a $9.3-\mathrm{m}^{2}$ circular quadrat on the 15 even-numbered plots. Trees representing different size classes in each treatment were cored and aged. We were unable to locate the exact boundaries of the original control area; therefore, we sampled an area near the original control site that conformed to the initial criteria and that probably contained part of the original site.

Reliable data on changes in wild ungulate and cattle grazing pressure on the Pine Hollow site over the 19 years are not available. We know, however, that although prudent management dictated reduction in numbers of livestock from their high levels early in the century, substantial numbers of cattle were in the area over the period of this study. Cattle did not use the site during 1966 (Davis 1989). We also know that the general area is within an important deer and elk range. Interpretation of vegetation differences between treatments is therefore based upon the presence or absence of cattle use versus wild ungulate use rather than on absolute changes in animal numbers.
Statistical analysis of vegetation production and sucker numbers included an analysis of variance to determine if differences exist for main effects:

(1) treatment (two exclosures and an open area) and

(2) years (1984 minus 1965) and treatment-year interaction. Tests using Tukey's multiple comparison procedure were used to determine differences that existed within treatments.

\section{RESULTS AND DISCUSSION}

Manipulation of aspen ecosystems by spraying or other means (such as burning or cutting) has been used to set back plant succession and to perpetuate the aspen community (Bartos and Lester 1984). Usually, however, these treatments are done under conditions of use (sometimes heavy) by livestock or wild ungulates or both. The primary purpose of this study was to show the effects of livestock and wildlife on aspen regeneration and understory production following site manipulation.

Prior to treatment in 1965 , the Pine Hollow site consisted of scrubby aspen interspersed with sage. brush dominated meadows (fig. 1). Total understory production sampled in mid-June 1965 was quite low, about $366 \mathrm{~kg} / \mathrm{ha}$. Most of this pretreatment understory production consisted of grasses and forbs characteristic of the site.

Changes that occurred on the site due to treatment are pronounced when viewed for the entire 19 years as evidenced by pictures of the game exclosure (figs. 2,3,4). Three years after spraying (fig. 3), the aspen overstory was uniformly killed across the treated area. Aspen subsequently reestablished itself where it was totally protected from animal use (fig. 4).

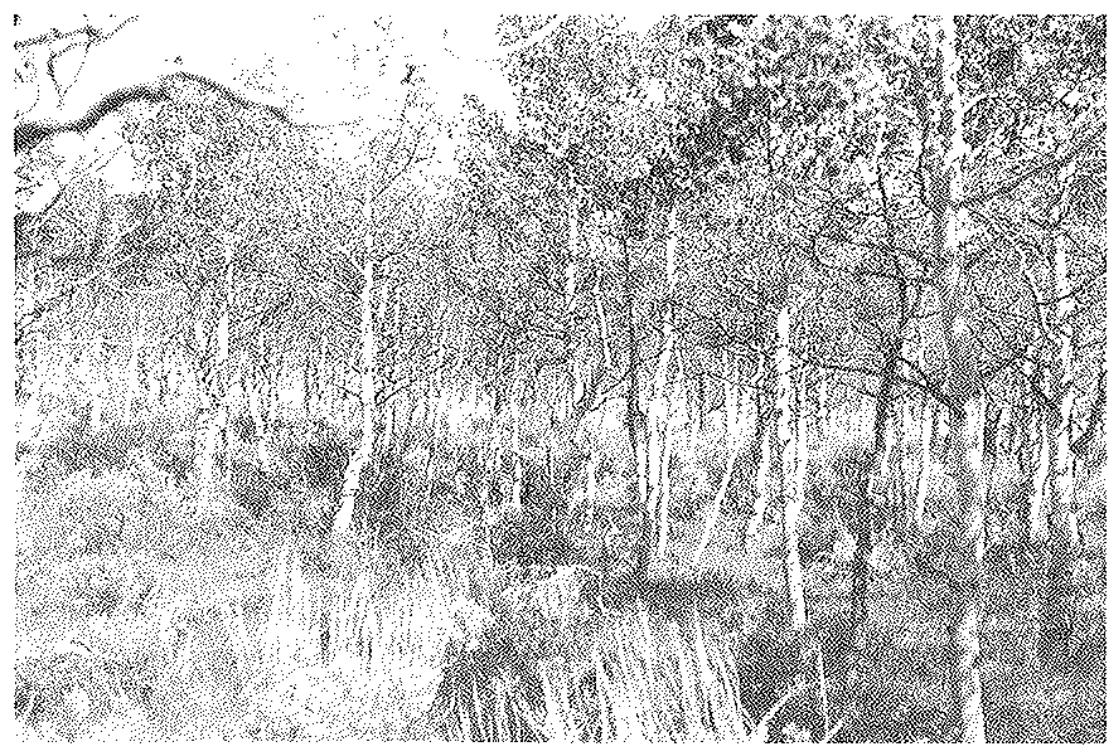

Figure 2-General view of game exclosure in 1965 prior to treatment by herbicide. 

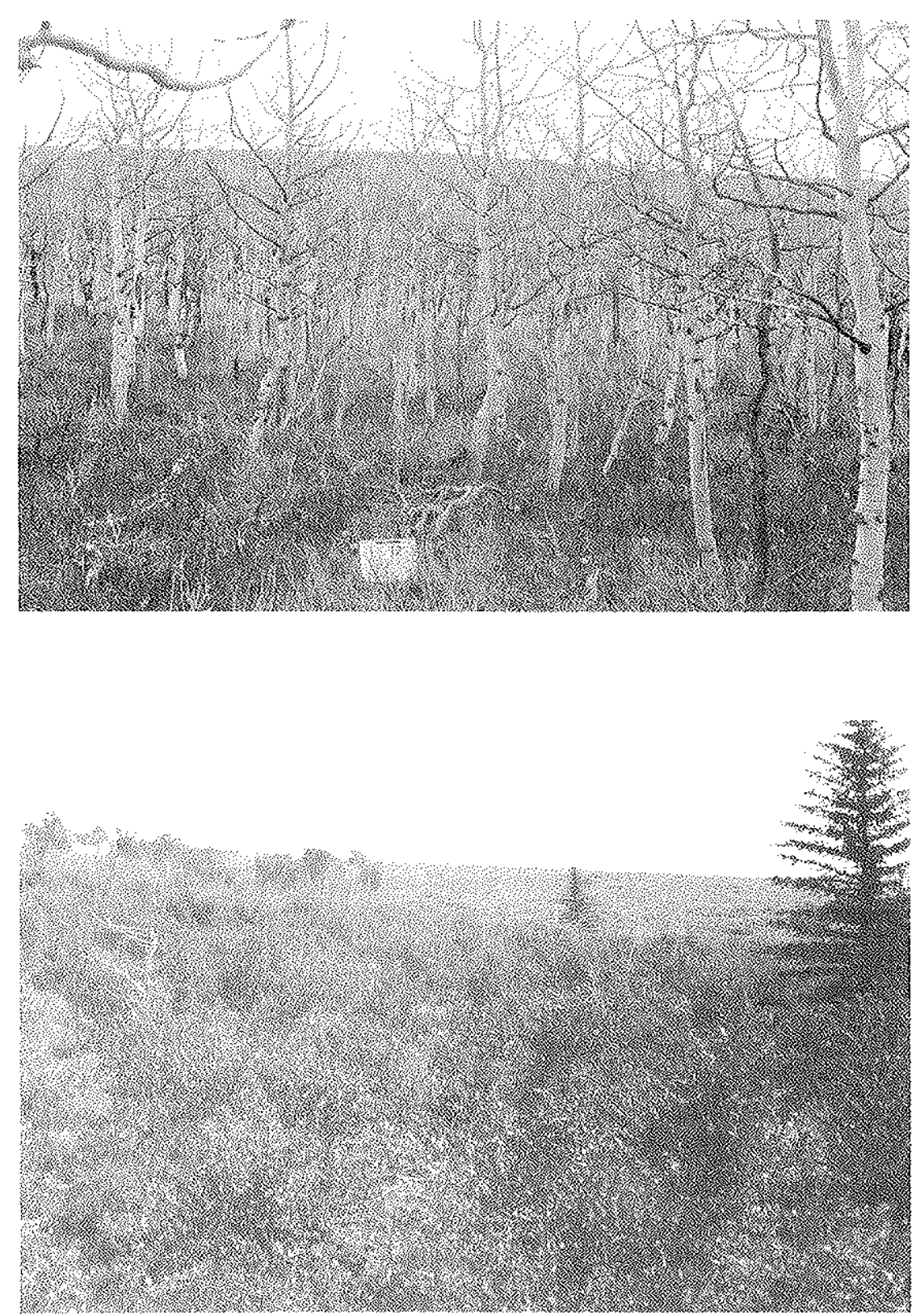

Figure 3-General view of game exclosure in 1968 showing dead aspen that resulted from treatment by herbicide.
Figure 4-General view of game exclosure in 1984 showing current condition of aspen protected from use.

\section{Tree Response}

Prior to treatment, the scrubby aspen on the site were 50 to 90 years old and were usually less than $9 \mathrm{~m}$ tall. Early observers of the site stated that aspen heart rot was common. As indicated above, all of the mature trees were killed by the herbicide.

The initial control area was selected for comparability of the aspen clone to the clone on the treated area. The control area selected in 1984 was near the original control site and may have contained part of it. The following information was obtained from the dominant trees on the 1984 control: mean age 68 years, range 43 to 83 years; mean height $11 \mathrm{~m}$, range 5.5 to $14 \mathrm{~m}$; and mean diameter at breast height $21.3 \mathrm{~cm}$, range 12.5 to $26.7 \mathrm{~cm}$. Keep in mind these values were obtained 19 years after the study was established.

When the aspen overstory is killed by spraying (as with any other type of manipulation) an ample number of aspen suckers usually occurs to reestablish the stand (Harniss and Bartos 1985). Pine Hollow was no exception. Peak numbers of suckers occurred shortly after treatment (fig. 5). These values were achieved in the open area $(8,649$ suckers/ha) in 1966 and in both the game $(21,498$ suckers/ha) and livestock (21,251 suckers/ha) exclon. sure in 1968. The control area had 14,579 suckers/ ha in 1965 and only 4,695 suckers/ha in 1984. By 1984 , sucker numbers decreased to about 4,942/ha in both the exclosures and only $1,236 /$ ha in the open 


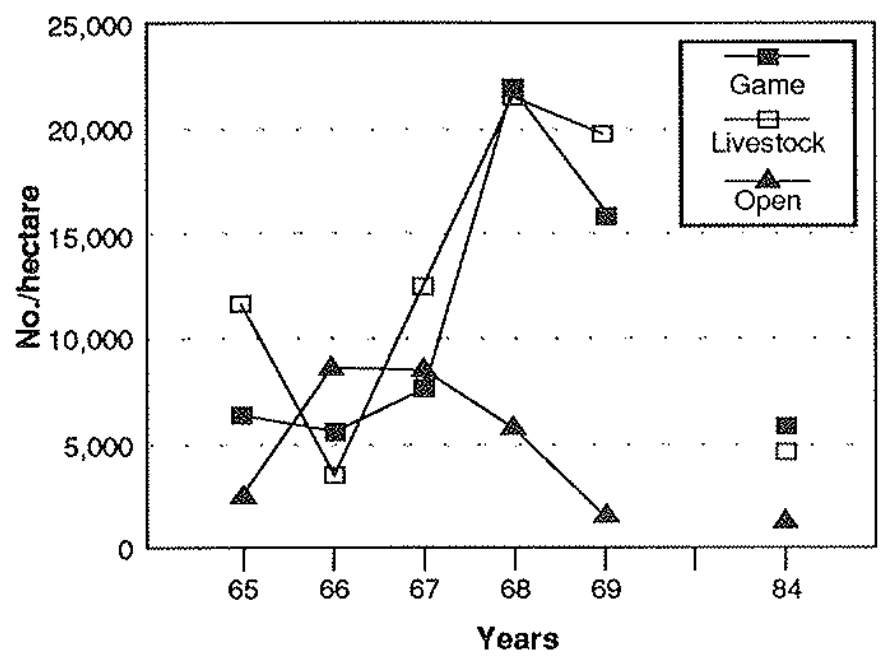

Figure 5-Number of aspen suckers produced for the 6 sample years on the three treatments.

area. These declines can be attributed to natural mortality and animal use. A fenceline comparison (fig. 6) between the game exclosure and open area for all animal use shows differences between the two areas. Suckers in both exclosures are developing into trees similar to what occurred prior to treatment. However, suckers in the open area, as well as the control, are small and less vigorous (we observed many to have been repeatedly browsed).

The difference in sucker numbers in 1965 between the open area (south end of the clone) and the game exclosure (north end of the clone) is attributed in large part to soil differences (Davis 1989). In the game exclosure we observed a 3.5 -fold increase, in the livestock exclosure a 1.8-fold increase, and in the open area a 3.7-fold increase. These increases are low compared to a twenty-fold increase in sucker production reported for an aspen clearcut in southern Utah (Mueggler and Bartos 1977). All of the suckers measured at Pine Hollow are less than the maximum of 76,000 /ha that we reported for 34 sprayed sites in the Western United States (Harniss and Bartos 1985). Most of the aspen stands associated with sagebrush spraying were on dry sites or had poor site quality. The Pine Hollow stands are of poor quality based on the regeneration measured and the earlier descriptions of the site.

Numbers alone do not tell the whole story about aspen suckers within the three treated areas. The game and livestock exclosures had virtually the same number of suckers after 19 years, but they were distributed differently. Within the game exclosure suckers were uniformly distributed across the site, while in the livestock exclosure suckers were primarily confined to the upper northwest quarter of the exclosure. We attribute these differences within the two exclosures to clonal pattern, soil differences (Davis 1989), or a combination of the two. In the open area where suckers occurred, however, they were not real visible. Those observed in 1984 were short and were either repeatedly browsed back or were not over 1 or 2 years old.

Deer and elk use in the livestock exclosure and the open area was approximately 25 deer-days and 25 elk-days/ha/yr for most of the first 5 years. However, in 1969 there was more than a doubling of deer use in the livestock exclosure. This extra animal pressure may have resulted in fewer suckers surviving in this exclosure.

Suckers from these scrubby aspen appear to be less vigorous than suckers on normal sites. In 1968, peak number of suckers $(21,498 / \mathrm{ha})$ occurred in the

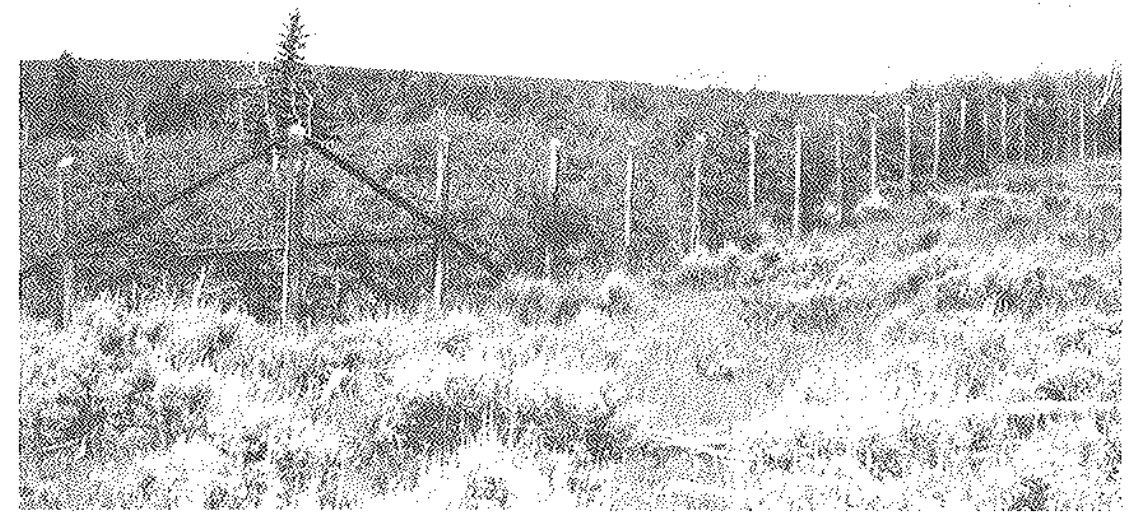

Figure 6-Fence line comparison between the game exclosure and open area. 
Table 1-Suckers (percent) by size categories that occurred on the three treatments at Pine Hollow 1984

\begin{tabular}{lccc}
\hline \multirow{2}{*}{ Treatment } & \multicolumn{3}{c}{ Sucker categories } \\
\cline { 2 - 4 } & $<0.5 \mathrm{~m}$ & $0.5-2 \mathrm{~m}$ & $>2 \mathrm{~m}$ \\
\hline & $\ldots \ldots \ldots$ Percent $\ldots \ldots \ldots$ & \\
Open-sprayed & 50 & 39 & 11 \\
Livestock enclosure & 11 & 78 & 11 \\
Game enclosure & 3 & 36 & 11 \\
\hline
\end{tabular}

game exclosure. However, they were hardly visible (fig. 3). By 1984, the game exclosure site was still fully stocked with young aspen trees. We consid. ered all stems as suckers even though some were taller than $2 \mathrm{~m}$, which is the usual dividing line between suckers and trees. Suckers greater than $2 \mathrm{~m}$ had an average age of 15.6 years, with a range of 11 to 19 years; those 0.5 to $2 \mathrm{~m}$ had an average age of 15 years, with a range of 7 to 19 ; and those less than $0.5 \mathrm{~m}$ had an average age of 5.3 years, with a range of 3 to 8 years.

Distribution of aspen suckers by size categories (table 1) is a good indicator of sucker response to spraying with herbicide and browsing. In the open area, 50 percent of the suckers were less than $0.5 \mathrm{~m}$ tall, while 61 percent were greater than $2 \mathrm{~m}$ tall in the wildlife exclosure. Most of the suckers in the livestock exclosure (78 percent) occurred in the 0.5- to 2-m-tall category.
Aspen composition of total undergrow th vegetation paralleled the amount of protection provided by the exclosures. The vegetative component in 1984 contained 53 percent aspen suckers in the wildlife exclosure, 13 percent in the livestock exclosure, and less than 1 percent in the open area. Distribution of sucker composition substantiates the fact that browsing by animals has a negative effect on aspen reproduction.

\section{Response of Understory Vegetation}

Understory vegetation production was summarized by categories for each treatment (table 2 ). Grasses responded to spraying with a tenfold increase in production the year following treatment regardless of location in or out of the exclosures. However, it did not remain high for the entire period. This agrees with observations made in Canada by Hilton and Bailey (1974) who found initial increases in grass and grasslike species. No definitive trend was observed in the forb category, but basically it remained static for the first 4 years after treatment. There was no marked reduction in forbs as a result of spraying, as Bowes (1978) reported for aspen in western Canada. Shrubs showed an increase that was most pronounced for the open area in 1984. These results agree in large part with expectations of broadleaf herbicide treatments (Anderson 1977).

Understory production was poor prior to treatment. All understory categories increased as a

Table 2-Vegetation production $(\mathrm{kg} / \mathrm{ha}$ ) for three freatments applied on the Pine Hollow site in eastern Utah

\begin{tabular}{|c|c|c|c|c|c|c|}
\hline Treatment & 1965 & 1966 & 1967 & 1968 & 1969 & 1984 \\
\hline \multicolumn{7}{|c|}{ Game exclosure } \\
\hline Grasses & 90 & 975 & 537 & 653 & 523 & 581 \\
\hline Forbs & 158 & 186 & 216 & 114 & 163 & 633 \\
\hline Shrubs & 112 & 66 & 21 & 278 & 151 & 653 \\
\hline Total & 360 & 1,227 & 775 & 1,046 & 837 & 1,867 \\
\hline \multicolumn{7}{|c|}{ Livestock exclosure } \\
\hline Grasses & 124 & 1,302 & 493 & 766 & 912 & 1,046 \\
\hline Forbs & 154 & 137 & 189 & 90 & 126 & 466 \\
\hline Shrubs & 74 & 74 & 30 & 136 & 107 & 426 \\
\hline Total & 353 & $\{, 488$ & 713 & 946 & 1,144 & 1,938 \\
\hline \multicolumn{7}{|c|}{ Open sprayed } \\
\hline Grasses & 121 & 1,079 & 503 & 562 & 521 & 680 \\
\hline Forbs & 180 & 209 & 225 & 165 & 170 & 353 \\
\hline Shrubs & 45 & 56 & 45 & 146 & 195 & 4,520 \\
\hline Total & 346 & 1,344 & 773 & 872 & 887 & 5,555 \\
\hline
\end{tabular}


result of removing the aspen overstory by herbicide. It is difficult to say anything definitively about trends because of the compounding factor of use or nonuse by large herbivores. Most of the shrub category in 1984 consisted of common juniper (fig. 7). The abundance of juniper was most dramatic in the open sprayed area that was used by all large herbi. vores. One explanation for the large increase in juniper would be the combination of tree removal (both overstory and suckers) and the continued use, by animals, of the competing forbs and grasses.

One of the primary purposes of resampling the Pine Hollow plots was to see what changes had occurred over time for the three exclosure treatments. Significant differences were observed for each vegetation type (grass, forb, shrub, and total) for the main effect of years (1965 vs. 1984). Mean differences (1984 minus 1965) and associated 95 percent confidence limits were plotted (fig. 8). For the main effect, treatment, we did not find statistically significant differences for each vegetation type as we had for the years effect. Further analyses were done to determine the cause of the differences observed in the two main effects.

All three treatments produced significantly $(P=0.05)$ more grass in 1984 than prior to treatment in 1965 (fig. 8A). This increase is due in part to the effects of herbicide and various combinations of protection. There were significantly more forbs produced (fig. 8B) in 1984 than in 1965 for the game and livestock exclosures. However, the open area showed differences that were not statistically different. We infer that after 19 years of large ungulate use, forb production remained relatively stable and where protected there were significant changes.

Just the opposite occurred with shrubs (fig. 8C). The open area produced significantly more shrubs in 1984 than in 1965, which can be attributed solely to the presence of common juniper. The two exclosures showed some difference in the amount of shrubs produced. However, they were not statistically significant. Total understory production (fig. 8D) was dominated by shrubs, and trends for the exclosure were similar to what was observed for the shrub category.

Shrubs were a consistent portion of the total production for the game exclosure (31 percent for 1965 , 35 percent for 1984) and livestock exclosure (21 percent for 1965, 22 percent for 1984). However, the open area was different (13 percent for 1965, 81 percent for 1984). Suppression of competing species by ungulates may have contributed to the prolifera. tion of common juniper in the open area or it may be due to site condition. This area is at the toe of a slight ridge and, therefore, may be wetter.

All the analyses done for the various vegetation categories were conservative. Therefore, no separation occurred for the three exclosure treatments. At this level of analysis, we only found separation for the main effect of years.

Early workers assigned individual plant species to the following desirability categories for ungulate use: desirable (such as Carex spp., Stipa comata Trin. \& Rupr., Agropyron smithii Rydb., geranium, lupine, and so forth); intermediate (Poa pratensis L., Stipa lettermani Vasey, Galium boreale L., aster, Smilacina spp., big sagebrush, Rosa woodsii Lindl., and so forth); and least desirable (Collinsia spp., Senecio spp., common juniper, and so forth). We duplicated this effort, and comparisons were made between 1965 and 1984 (fig. 9). Excluding all use favored desirable and intermediate species with a marked reduction in least desirable species. We saw the opposite occur for the livestock exclosure

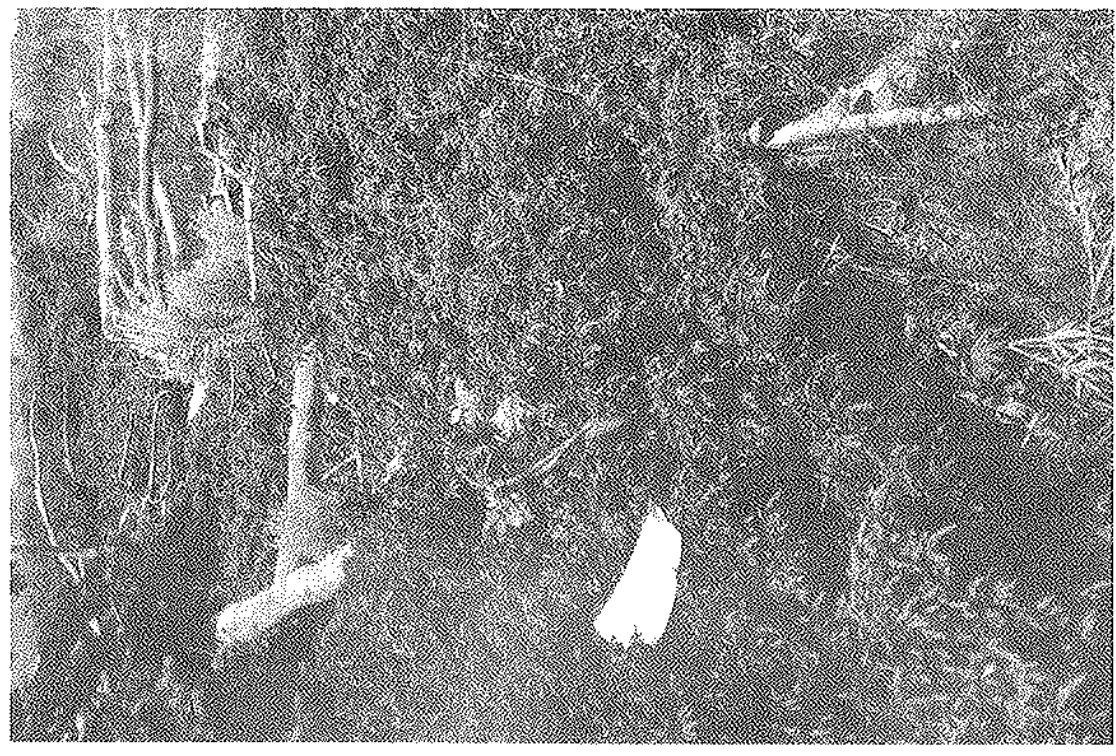

Figure 7-Dense common juniper as it occurred in 1984 on the area open to all use. 

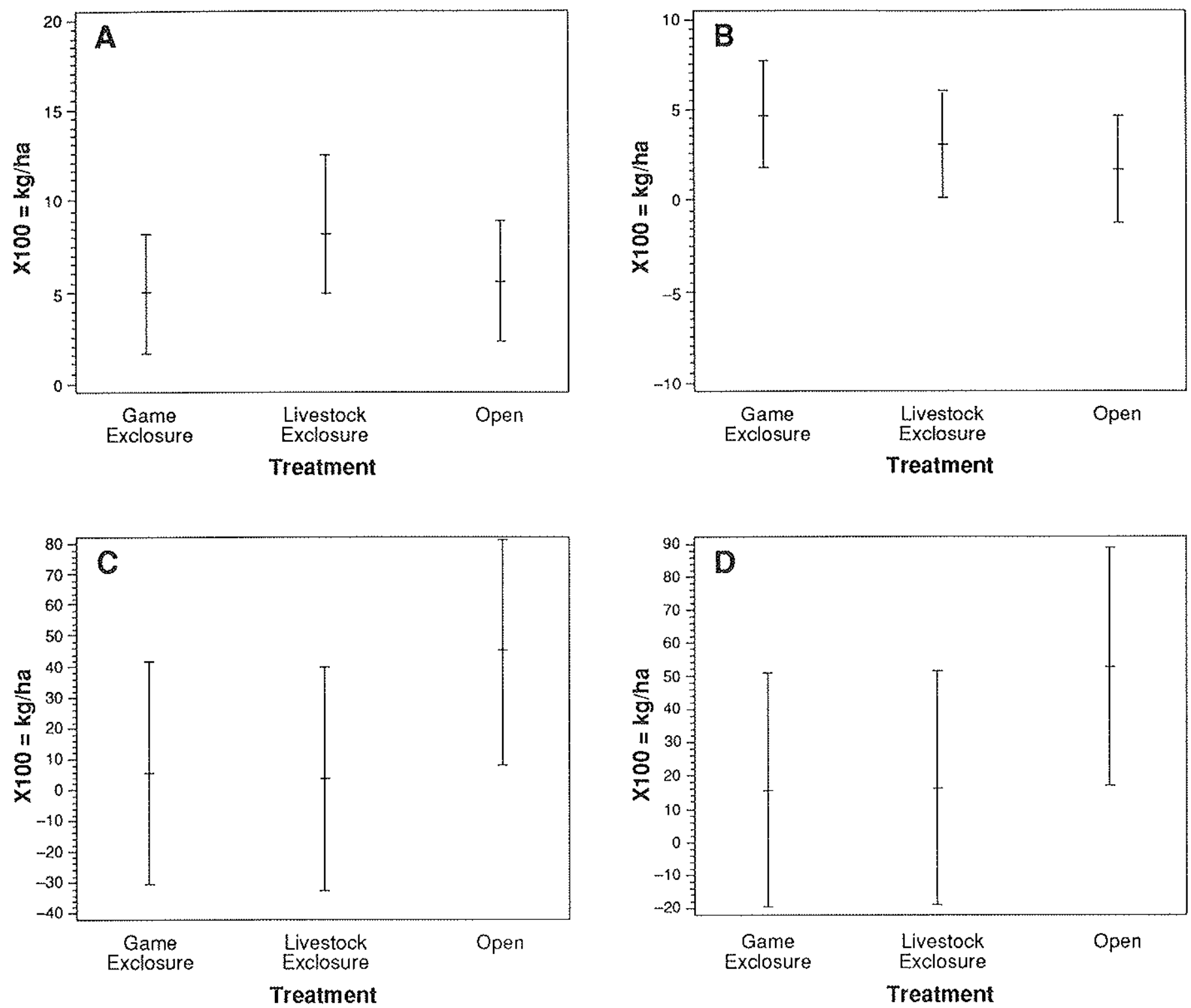

Figure 8-Mean differences (1984 minus 1965) plus or minus 95 percent confidence limits for grasses $(A)$, forbs $(B)$, shrubs $(C)$, and total production (D).

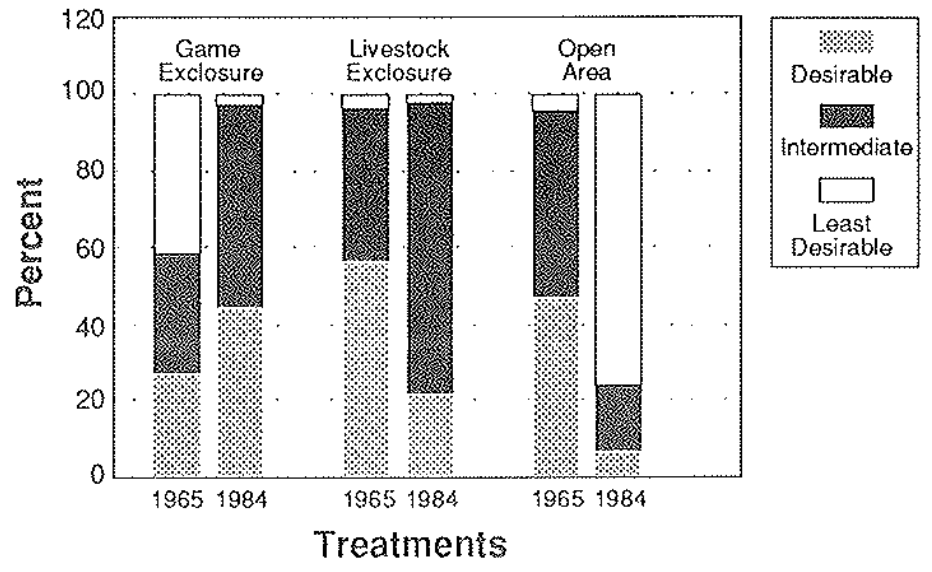

Figure 9-Species desirability for three treatment areas. 
and open area. Where just livestock were excluded there was a decline in desirable and least desirable species and a doubling of intermediate species. A sharp increase in least desirable (common juniper) was found in the open area. Similar shifts in composition were seen on the control area as were seen in the open-sprayed area but of less magnitude. Increases in least desirable species occurred even though the site was not sprayed. These shifts in species dramatize the effect animal use has on the system.

\section{ACKNOWLEDGMENTS}

We wish to acknowledge the contribution of the Ashley National Forest personnel involved in establishing the plots and gathering the initial data. Thomas H. Sevy prepared the study plan in 1965. Data were collected for the first 5 years by Alan Partridge and associates (Henrie, Haussler, Bench, Shippee, Julien, and Prescott). Partridge summarized the initial data through 1969 , which assisted in the interpretation of the early work. Historical perspective was provided by Bill Davis, Gary Lange, Floyd Bartlett, and Alan Partridge.

\section{REPERENCES}

Anderson, W. P. 1977. Weed science: principles. New York: West Publishing Company. 598 p.

Bartos, D. L.; Lester, J. E. 1984. Effects of 2,4-D on a Populus tremuloides community in the Western United States-22 years after treatment. Great Basin Naturalist. 44(3): $459-467$.

Bowes, G. G. 1978. Advantages of herbicides for brush control on newly seeded rangeland in western Canada. In: Hyder, D. N., ed. Proceedings first international rangeland congress. Denver, CO: Society of Range Management: 651-653.

Davis, William. 1989. [Personal communications]. June 20. U.S. Department of Agriculture, Forest Service, Intermountain Region (retired).

Harniss, R. O.; Bartos, D. L. 1985. Survey of aspen stands treated with herbicides in the Western United States. Res. Pap. INT-340. Ogden, UT: U.S. Department of Agriculture, Forest Service, Intermountain Research Station. 6 p.

Hilton, J. E.; Bailey, A. 1974. Forage production and utilization in a sprayed aspen forest in Alberta. Journal of Range Management. 27(5): 375-380.

Laycock, W. A. 1969. Exclosures and natural areas on rangelands in Utah. Res. Pap. INT-62. Ogden, UT: U.S. Department of Agriculture, Forest Serv. ice, Intermountain Forest and Range Experiment Station. $44 \mathrm{p}$.

Mueggler, W. F. 1988. Aspen community types of the Intermountain Region. Gen. Tech. Rep. INT-250. Ogden, UT: U.S. Department of Agriculture, Forest Service, Intermountain Research Station. $135 \mathrm{p}$.

Mueggler, W. F.; Bartos, D. L. 1977. Grindstone Flat and Big Flat exclosures-41-year record of changes in clearcut aspen communities. Res. Pap. INT-195. Ogden, UT: U.S. Deparment of Agriculture, Forest Service, Intermountain Forest and Range Experiment Station. 16 p.

U.S. Department of Agriculture, Forest Service. 1983. Range analysis handbook. FSH 2209.21 R-4. Ogden, UT: U.S. Department of Agriculture, Forest Service, Intermountain Region. 


\section{PESTICIDE PAECAUTIONARY STATEMENT}

This publication reports research involving pesticides. It does not contain recommendations for their use, nor does it imply that the uses discussed here have been registered. All uses of pesticides must be registered by appropriate State and/or Federal agencies before they can be recommended.

CAUTION: Pesticides can be injurious to humans, domestic animals, desirable plants, and fish or other wildlife - if they are not handled or applied properly. Use all pesticides selectively and carefully. Follow recommended practices for the disposal of surplus pesticides and pesticide containers.

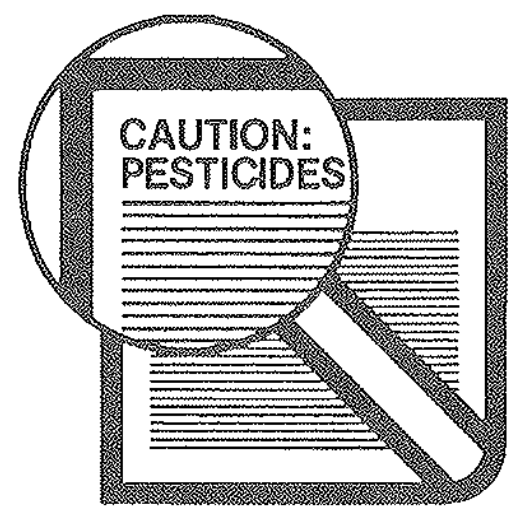

Intermountain Research Station

324 25th Street

Ogden, UT 84401 


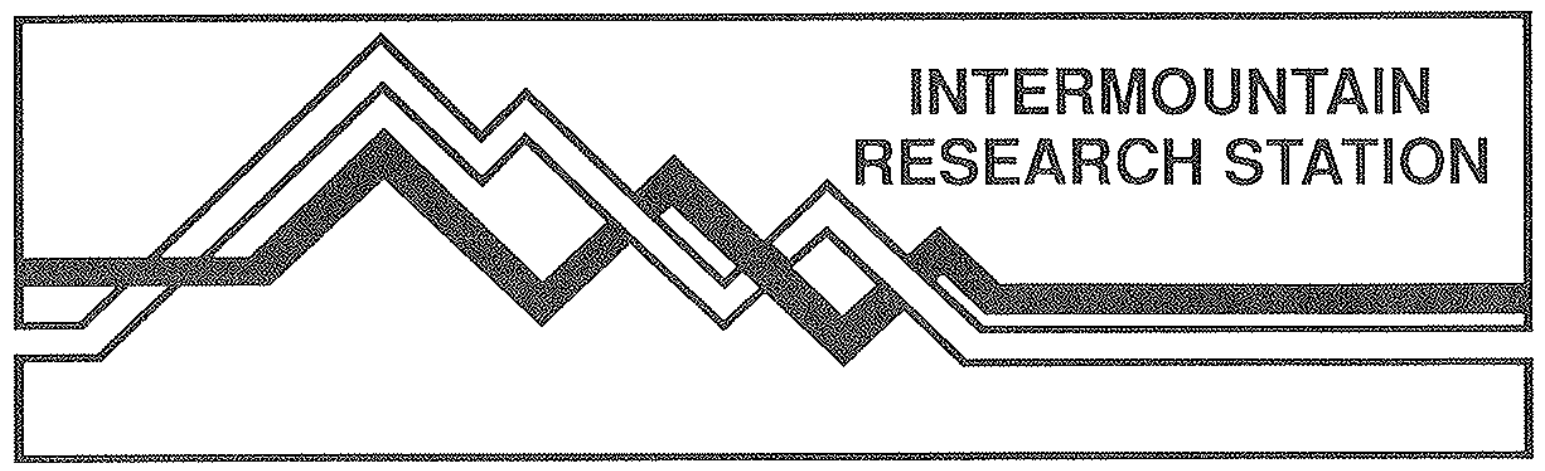

The Intermountain Research Station provides scientific knowledge and technology to improve management, protection, and use of the forests and rangelands of the Intermountain West. Research is designed to meet the needs of National Forest managers, Federal and State agencies, industry, academic institutions, public and private organizations, and individuals. Results of research are made available through publications, symposia, workshops, raining sessions, and personal contacts.

The Intermountain Research Station territory includes Montana, Idaho, Utah, Nevada, and western Wyoming. Eighty-five percent of the lands in the Station area, about 231 million acres, are classified as forest or rangeland. They include grasslands, deserts, shrublands, alpine areas, and forests. They provide fiber for forest industries, minerals and fossil fuels for energy and indusirial development, water for domestic and industrial consumption, forage for livestock and wild life, and recreation opportunities for millions of visitors.

Several Station units conduct research in additional western States, or have missions that are national or international in scope.

Station laboratories are located in:

Boise, Idaho

Bozeman, Montana (in cooperation with Montana State University)

Logan, Utah (in cooperation with Utah State University)

Missoula, Montana (in cooperation with the University of Montana)

Moscow, Idaho (in cooperation with the University of Idaho)

Ogden, Utah

Provo, Utah (in cooperation with Brigham Young University)

Reno, Nevada (in cooperation with the University of Nevada)

USDA policy prohibits discrimination because of race, color, national origin, sex, age, religion, or handicapping condition. Any person who believes he or she has been discriminated against in any USDA-related activity should immediately contact the Secretary of Agriculture, Washington, DC 20250. 